\title{
Intravascular Large B-Cell Lymphoma of the Gallbladder
}

\author{
Safra Kesesinin Intravasküler Diffüz Büyük Hücreli Lenfoması
}

\author{
(D) Bülent Çetin1, (DD Nalan Akyürek², (D) Yavuz Metin³, (D) Feryal Karaca4, (D) İrem Bilgetekin5, (D) Ahmet Özet6 \\ ${ }^{1}$ Recep Tayyip Erdoğan University Faculty of Medicine, Department of Internal Medicine, Division of Medical Oncology, Rize, Turkey \\ ${ }^{2}$ Gazi University Faculty of Medicine, Department of Pathology, Ankara, Turkey \\ ${ }^{3}$ Recep Tayyip Erdoğan University Faculty of Medicine, Department of Radiology, Rize, Turkey \\ ${ }^{4}$ Adana Numune Training and Research Hospital, Clinic of Radiation Oncology, Adana, Turkey \\ ${ }^{5}$ Dr. Abdurrahman Yurtaslan Ankara Oncology Training and Research Hospital, Clinic of Internal Medicine, Division of Medical Oncology, \\ Ankara, Turkey \\ ${ }^{6}$ Gazi University Faculty of Medicine, Department of Internal Medicine, Division of Medical Oncology, Ankara, Turkey
}

\section{To the Editor,}

Intravascular large B-cell lymphoma (IVLBCL) is a rare type of extranodal B-cell lymphoma characterized by the growth of lymphoma cells within the lumina of small vessels. Two major patterns of clinical presentation have been recognized: the first is in European countries, with brain and skin involvement, and the second in Asian countries, where patients typically present with multiorgan failure, hepatosplenomegaly, pancytopenia, and hemophagocytic syndrome $[1,2,3,4,5]$. Primary IVLBCL of the gallbladder is exceedingly rare.

A 60-year-old male patient was admitted to the hospital with fever, abdominal pain, and weight loss. Physical examination showed an epigastric mass of approximately $4 \mathrm{~cm}$ in diameter and the absence of hepatosplenomegaly and lymphadenopathy. Laboratory tests revealed anemia (hemoglobin: $10 \mathrm{~g} / \mathrm{dL}$ ), with normal leukocytes and platelets. Peripheral smear showed normocytic-normochromic anemia without any abnormal cells. Increases in liver function tests were positive laboratory findings (aspartate aminotransferase: $240 \mathrm{U} / \mathrm{L}$, alanine aminotransferase: $240 \mathrm{U} / \mathrm{L}$, alkaline phosphatase: $740 \mathrm{U} / \mathrm{L}$, gamma-glutamyl transferase: $80 \mathrm{U} / \mathrm{L}$, total bilirubin/direct bilirubin: $2.06 / 1.2 \mathrm{mg} /$ $\mathrm{dL}$ ). Contrast-enhanced abdominal computerized tomography (CT) for further evaluation revealed a greater curvature-based mass of $8 \times 5 \times 5.5 \mathrm{~cm}$ in size, at the level of the distal gastric corpus, significantly narrowing the gastric lumen (Figures $1 \mathrm{~A}$ and $1 \mathrm{~B}$ ). CT also showed hypodense areas in liver segments 5 and 8 and gallbladder stones, the largest being $1.5 \mathrm{~cm}$ in diameter. Dynamic liver magnetic resonance imaging (MRI) was performed to characterize the liver lesions. MRI revealed calculous cholecystitis, choledocholithiasis, and a mass lesion of $6.5 \times 3 \mathrm{~cm}$ in size, thought to be based on the greater curvature at the corpus of the stomach. With no signs of distant metastasis, the patient primarily underwent both cholecystectomy and partial gastrectomy. Surgical biopsy of liver lesions revealed nonspecific inflammatory changes and no evidence of a tumor, while histologic examination confirmed a gastrointestinal

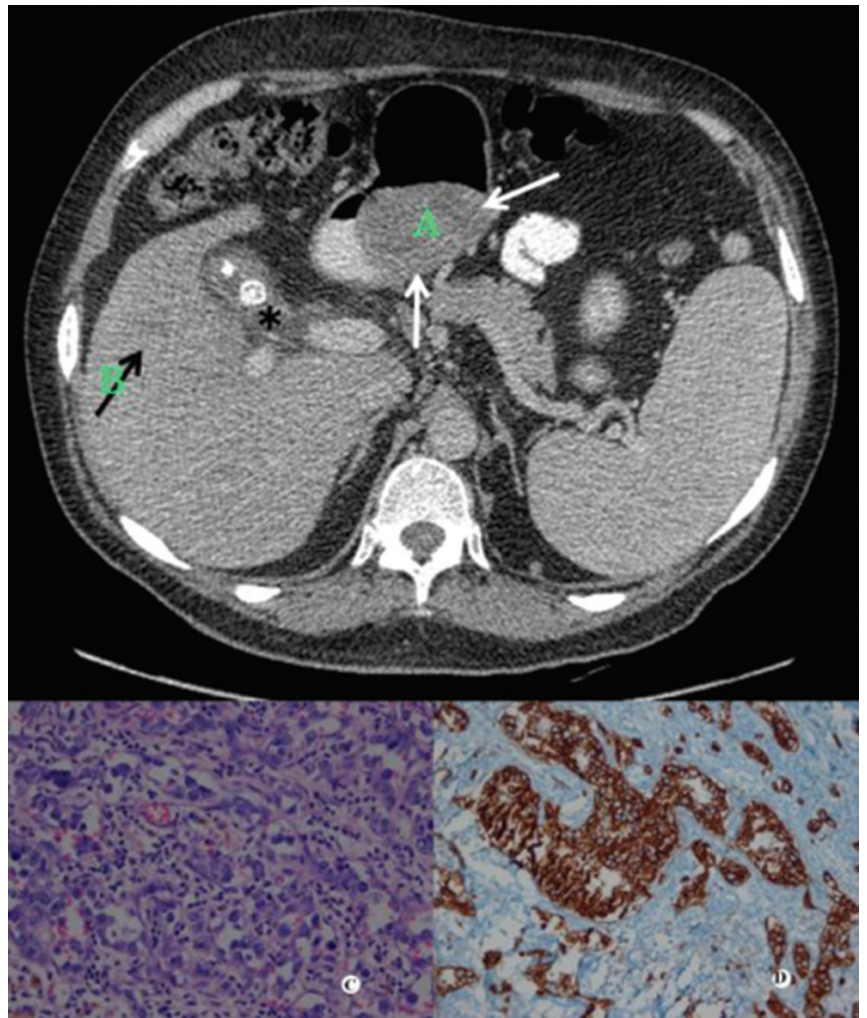

Figure 1. A, B) Axial computerized tomography image showing a greater curvature-based intraluminal gastric mass (white arrows), stones in the gallbladder (asterisk), and a vague hypodense area, which was proven to be caused by cholangitis, in segment 5 of the liver (black arrow). C) Intravascular B-cell lymphoma. The numerous dilated blood vessels were filled with large, atypical, centroblast-like lymphoid cells (hematoxylin and eosin, 400x). D) CD20-positive atypical lymphoid cells (400x).

stromal tumor (GIST) of the stomach. Histological analysis of the cholecystectomy material showed cells with irregular nuclear contours and open chromatin confined to small vessels, characteristic of the IVLBCL phenotype. These cells were strongly positive for CD20 stain (Figures 1C and 1D). Since intravascular infiltrations are easily missed on hematoxylin and eosin-stained sections, bone marrow and liver biopsy slides were also stained 
by CD20 and no evidence of intravascular lymphoma was found. A whole-body integrated positron electron tomographyCT scan for tumor staging showed diffusely increased uptake of 18F-fludeoxyglucose in the liver (SUV $\left.{ }_{\text {max }}: 7.0\right)$ and multiple lymph node lesions including the submandibular, preauricular, cervical, and jugular lymph nodes (SUV $\left.{ }_{\text {max }}: 8.3\right)$. He was treated with six cycles of an R-CHOP regimen. He did not show any evidence of recurrence (normal gastroscopy and CT scan) at 36 months of follow-up.

IVLBCL usually occurs in adults in the sixth and seventh decades. The tumor is often clinically unsuspected and can be easily overlooked on biopsy. The diagnosis is most commonly made at autopsy. The lymphoma cells are generally large with round nuclei and prominent nucleoli. The malignant cells uniformly express pan-B-cell antigens (CD20, CD79a) and variably express other antigens such as CD5 (38\%) and CD10 (13\%) [2]. There are no pathognomonic laboratory or radiologic abnormalities associated with IVLBCL. Abdominal CT and MRI findings of our patient with IVLBCL were nonspecific. What is the pathogenic mechanism for simultaneous presentation of gallbladder intravascular B-cell lymphoma with GIST? A unifying hypothesis supports a single underlying genetic instability that could have led to both diseases. The finding of two different neoplasms in our patient seems to be coincidental rather than related to the same pathogenic triggering. Central nervous system symptoms, skin manifestations, bone marrow involvement, and hemophagocytic syndrome are the most common clinical and laboratory abnormalities, but these were not seen in our case. Our patient presented with nonspecific symptoms and laboratory abnormalities. The ability of IVLBCL to involve any organ system further makes it very difficult to suspect this condition in a patient with a rare presentation such as ours.
Keywords: Intravascular large B-cell lymphoma, Gallbladder, Gastrointestinal stromal tumor

Anahtar Sözcükler: İntravasküler büyük hücreli lenfoma, Safra kesesi, Gastrointestinal stromal tümör

Conflict of Interest: The authors of this paper have no conflicts of interest, including specific financial interests, relationships, and/or affiliations relevant to the subject matter or materials included.

\section{References}

1. Ferreri AJ, Campo E, Seymour JF, Willemze R, llariucci F, Ambrosetti A, Zucca E, Rossi G, López-Guillermo A, Pavlovsky MA, Geerts ML, Candoni A, Lestani M, Asioli S, Milani M, Piris MA, Pileri S, Facchetti F, Cavalli F, Ponzoni M; International Extranodal Lymphoma Study Group (IELSG). Intravascular Iymphoma: clinical presentation, natural history, management and prognostic factors in a series of 38 cases, with special emphasis on the "cutaneous variant." Br J Haematol 2004;127:173-183.

2. Ferreri AJ, Dognini GP, Campo E, Willemze R, Seymour JF, Bairey O, Martelli M, De Renz A0, Doglioni C, Montalbán C, Tedeschi A, Pavlovsky A, Morgan S, Uziel L, Ferracci M, Ascani S, Gianelli U, Patriarca C, Facchetti F, Dalla Libera A, Pertoldi B, Horváth B, Szomor A, Zucca E, Cavalli F, Ponzoni M; International Extranodal Lymphoma Study Group (IELSG). Variations in clinical presentation, frequency of hemophagocytosis and clinical behavior of intravascular lymphoma diagnosed in different geographical regions. Haematologica 2007;92:486-492.

3. Murase T, Nakamura S. An Asian variant of intravascular lymphomatosis: an updated review of malignant histiocytosis-like B-cell lymphoma. Leuk Lymphoma 1999;33:459-473.

4. Murase T, Nakamura S, Kawauchi K, Matsuzaki H, Sakai C, Inaba T, Nasu K, Tashiro K, Suchi T, Saito H. An Asian variant of intravascular large B-cell lymphoma: clinical, pathological and cytogenetic approaches to diffuse large $\mathrm{B}$-cell lymphoma associated with haemophagocytic syndrome. $\mathrm{Br} \mathrm{J}$ Haematol 2000;111:826-834.

5. Shimazaki C, Inaba T, Nakagawa M. B-cell lymphoma-associated hemophagocytic syndrome. Leuk Lymphoma 2000;38:121-130.
Address for Correspondence/Yazışma Adresi: Bülent ÇETiN, M.D.,

Recep Tayyip Erdoğan University Faculty of Medicine, Department of Internal Medicine,

Division of Medical Oncology, Rize, Turkey

Phone : +905058842694

E-mail : caretta06@hotmail.com ORCID-ID: orcid.org/0000-0001-8628-0864
Received/Geliş tarihi: July 24, 2017

Accepted/Kabul tarihi: January 26, 2018

DOI: 10.4274/tjh.2017.0276 